\title{
ANTIOXIDANT EFFECTS OF MUEHLENBECKIA HASTULATA J. (POLYGONACEAE) EXTRACTS
}

\author{
MARCO MELLADO ${ }^{1 *}$, ALEJANDRO MADRID ${ }^{1}$, CARLOS JARA ${ }^{2}$, LUIS ESPINOZA ${ }^{1 *}$ \\ ${ }^{\perp}$ Departamento de Química, Universidad Técnica Federico Santa María, Av. España $N^{\circ} 1680$, Valparaíso, Chile. \\ ${ }^{2}$ Laboratorio de Radicales Libres, Universidad de Valparaíso, Gran Bretaña 1111, Valparaíso, Chile.
}

(Received: April 1, 2012 - Accepted: May 28, 2012)

\begin{abstract}
The antioxidant properties of different extracts of quilo (Muehlenbeckia hastulata J., Poligonaceae) herb from Valparaíso region in Chile were evaluated. Antioxidant activity was assessed in three different model systems. Antioxidant models were examined by measuring the scavenging activity of extracts on 2,2-diphenyl-1-pycrylhydrazil (DPPH ${ }^{\bullet}$ ). Moreover extracts were evaluated by ferric reducing antioxidant power (FRAP) and the total peroxyl radical-trapping potential (TRAP). The amount of dried extract, the content of total phenolics, flavonoids, hydrolyzed sugar and anthraquinones were also determined. Extracts pertaining to stem and root of the plants were the significant activities DPPH radical scavenging $\left(\mathrm{IC}_{50} 0.74 \mathrm{mg} / \mathrm{mL}\right.$ to $1.33 \mathrm{mg} / \mathrm{mL}$ the more active extracts). The activities and TRAP and FRAP high values in extracts of EtOAc (1.423 and $1.540 \mathrm{mM}$ TEAC) and ethanol (245.26 and $309.04 \mathrm{mM}$ TEAC) stem and root of the plant are higher.The observed differences in antioxidant activity among the different parts of quilo could be partially explained by the levels of phenolics compounds present in the root extract of EtOAc $(0.023 \mathrm{mg} \mathrm{GAE} / \mathrm{g}$ dry extract), flavonoids in the leaves of EtOAc extract (99.12 mg QE/g dry extract), hydrolyzed sugar in the ethanol extract $(21.87,14.85$ and $14.32 \mathrm{mg} \mathrm{GES} / \mathrm{g}$ dry extract of leaf, stem and roots, respectively) and anthraquinones in the EtOAc extracts (2.50, 1.43 and $0.84 \mathrm{mg} \mathrm{EE} / \mathrm{g}$ dry extract of leaf, stem and roots, respectively) .
\end{abstract}

Keywords: Muehlenbeckia hastulata, Polygonaceae, Antioxidant activity, DPPH radical, FRAP, TRAP, Total phenolics, Flavonoids, Hydrolyzed sugar and Anthraquinones.

\section{INTRODUCTION}

Since ancient times, plants have been used as novel therapeutic agents and their uses have been passed from generation to generation, orally or in writing. The importance of natural product in medicine, is not based only on their pharmacological or chemotherapeutic effects, but they offer the possibility to develop the new drugs structures ${ }^{1,3}$. Thus, phytochemicals and biochemistry of medicinal plant are of particular interest to many scientists, since they are widely used as nutrients, and the role they can play in the fight against diseases of the modern age (malignant tumors, cardiovascular disease, diabetes, rheumatism, Alzheimer's disease) and aging processes, are often connected with oxidative stress, reactive oxygen species (ROS) and lipid peroxidation $(\mathrm{LP})^{2-8}$.

A reactive oxygen species is effectively eliminated with the help of antioxidant compounds within which polyphenols are included ${ }^{10}$. Therefore, attention is focused on the use of antioxidants to protect cells from the biological damage due to free radicals and oxidants species. Antioxidants have been widely used as food additives (such as terbutyl-hydroxytoluene BHT-, terbutyl-4-hydroxyanisole - BHA - and propyl gallate - PG) to provide protection against oxidative degradation of foods and to measure its lifetime $\mathrm{e}^{3-6}$, 8,11 , but these compounds have been reported to be carcinogenic and hazardous for the human health. Hence, several attempts to replace synthetic antioxidants with natural antioxidants have been developed and investigated obtaining them from natural sources such as vegetables, fruits, leaves, bark, roots of plants, among others?.

Because the chemical diversity of the antioxidant compounds present in foods, complete databases on food antioxidant content are not yet available. Furthermore, levels of antioxidants in food alone does not necessarily reflect the total antioxidant capacity (TAC), which also depends on synergistic and redox interactions among different molecules present in food ${ }^{4}$.

Muehlenbeckia hastulata popularly known as quilo, is used by ancient cultures as diuretic and hypotensive, besides being used as compresses to relieve burns. The chemical composition of aerial part indicates the presence of tannins and flavonoids as routine and epicatechin. Moreover in the roots there are anthraquinones: chrysophanic acid, emodin, rhein, hypericin and protohypericin $^{12-16}$.

It has been described that the extract of the plant acts as an antiviral against influenza which has the chloroform extract of aerial part $(0.125 \mathrm{mg} / \mathrm{mL})$. Also, it has an oxitoxic effect (secretion of oxytocin promoter) of hexane root extract (62\% effectiveness of phenoterol and papaverin). Besides, it has a pain killer effect and a poor microbacterial activity against Escherichia coli, Klebsiella pneumoniae, Salmonella aviatum, Salmonella aeruginosa, Staphylococcus aureus, Micrococcus flavus y Bacillus subtilis (hexane, dichloromethane and ethanol extracts of aerial parts $)^{12,17}$.

In the present work we have made some phytochemical screens of hexane, $\mathrm{CH}_{2} \mathrm{Cl}_{2}$, EtOAc and ethanol crude of different parts (leaf, stem and root) extracts of Muehlenbeckia hastulata, total phenolics, flavonoids, hydrolyzed sugar and total anthraquinones content were quantified and the antioxidant activity of the extracts was determined in vitro by the neutralization of 2,2-diphenyl1-pycrylhydrazil $\left(\mathrm{DPPH}^{\bullet}\right)$ radical, as well as by ferric reducing antioxidant power (FRAP) and the total peroxyl radical-trapping potential (TRAP).

\section{EXPERIMENTAL PROCEDURES}

\subsection{Plant material}

The plant was collected in the geographical position $33^{\circ} 05^{\prime} 45^{\prime}, \mathrm{S}-71^{\circ}$ $35^{\prime} 17^{\prime \prime} \mathrm{W}$ at 460 meters of sea level in April 2011. Voucher specimen is kept in the Herbarium of the Natural Products Laboratory, "Dr. Herbert Appel A", UTFSM, Valparaíso, Chile (MHJ-2011). The plant was recognized by Rodrigo Villaseñor, professor of Biology and expert in botany, considering different morphological properties of the material.

\subsection{Extraction Procedure}

The plant material (leaves, stems and roots) was dried at room temperature and then was subjected to successive extractions with solvents of increasing polarity: hexane, dichloromethane, ethyl acetate and ethanol to total exhaustion. All extracts and fractions obtained were concentrated in a rotary evaporator at $40^{\circ} \mathrm{C}$ and then were taken to dry at room temperature in the dark.

\subsection{Determination of total phenolic content}

The amount of total phenolic compounds in extracts was determinated spectrophotometrically using Folin-Ciocalteu (FC) as reagent according to the method used by Waterman ${ }^{18}$ with small modifications Köhler ${ }^{19}$. Each extract sample $(5 \mathrm{mg})$ was diluted to $5 \mathrm{~mL}$ with ethanol. This solution $(0.5 \mathrm{~mL})$ was then mixed with $2.5 \mathrm{~mL}$ of $0.2 \mathrm{~N} \mathrm{FC}$ reagent for $5 \mathrm{~min}$ and $2 \mathrm{~mL} 7.5 \%$ sodium carbonate solution was then added. The mixture was incubated in the dark at room temperature for $2 \mathrm{~h}$. The absorbance of the resulting solution was measured at $700 \mathrm{~nm}$ on a UV-Vis spectrophotometer (Jenway 6320D, Bibby Scientific Limited, Beacon Road, Stone, Staffordshire ST15 0SA, UK) using ethanol as blank. The concentration of total phenolic compounds was expressed in $\mathrm{mg}$ of gallic acid equivalents (GAE) per g dried extract (d.e.), using a standard curve of gallic acid $(0-200 \mathrm{mg} / \mathrm{L})$ treated the same way as samples. All measurements were replicated three times.

\subsection{Estimation of total flavonoid content}

The total flavonoid content was determined using the Dowd method as adapted by Arvouet-Grand, Vennat, Pourrat, and Legret ${ }^{20}$. Briefly, $5 \mathrm{~mL}$ of $2 \%$ aluminium trichloride $\left(\mathrm{AlCl}_{3}\right)$ in ethanol was mixed with the same volume of extract solution in ethanol $(1.0 \mathrm{mg} / \mathrm{mL})$. Absorption readings at $415 \mathrm{~nm}$ were taken after $10 \mathrm{~min}$ against a blank sample consisting of a $5 \mathrm{~mL}$ extract solution with $5 \mathrm{~mL}$ methanol without $\mathrm{AlCl}_{3}$. The total flavonoid content was determined using a standard curve with quercetin $(0-70 \mathrm{mg} / \mathrm{L})$ as standard. The mean of 
three readings was used and expressed as mg of quercetin equivalents (QE)/ per g dry extract.

\subsection{Estimation of total hydrolyzed sugar content}

The total hydrolyzed sugar content was determinated using the method by Bruneton $^{21}$ and Domingue ${ }^{22}$ with modifications ${ }^{23}$. Briefly, $3 \mathrm{~mL}$ of ethanolics extracts were mixed with $4 \mathrm{~mL} 6 \mathrm{M} \mathrm{HCl}$ and $3 \mathrm{~mL}$ of distilled water. After incubation at room temperature for 4 days, this mixture was extracted with $5 \mathrm{~mL}$ of EtOAc, two times, then discard organic layer. The aqueous solution was dilute to $20 \mathrm{~mL}$. Then $1 \mathrm{~mL}$ extract were mixed with $1 \mathrm{~mL} 0.5 \%$ anthrone in ethanol and $5 \mathrm{~mL}$ of concentrate $\mathrm{H}_{2} \mathrm{SO}_{4}$. The mixture was cooled at room temperature for $10 \mathrm{~min}$. The absorbance of the resulting solution was measured at $621 \mathrm{~nm}$ using distilled water as the blank. The total hydrolyzed sugar content was determinated using a standard curve with glucose anhydrous (1 to 140 $\mathrm{mg} / \mathrm{L}$ ) as standard. The mean of three readings was used and expressed in $\mathrm{mg}$ glucose equivalents (GES) per g extract.

\subsection{Estimation of total anthraquinones content}

This estimate is taken as reference the total flavonoids according to the points made by Arvouet-Grand, Vennat, Pourrat, and Legret ${ }^{20}$ with modifications ${ }^{23}$. Briefly, $5 \mathrm{~mL}$ of $2 \%$ aluminium trichloride $\left(\mathrm{AlCl}_{3}\right)$ in ethanol was mixed with the same volume of extract solution in ethanol $(1.0 \mathrm{mg} / \mathrm{mL})$. Absorption readings at $415 \mathrm{~nm}$ were taken after 10 min against a blank sample consisting of a $5 \mathrm{~mL}$ extract solution with $5 \mathrm{~mL}$ of methanol without $\mathrm{AlCl}_{3}$. The total anthraquinone content was determined using a standard curve with emodine $(0-70 \mathrm{mg} / \mathrm{L})$ as the standard. The mean of three readings was used and expressed as $\mathrm{mg}$ of emodin equivalents (EE)/per g dry extract.

\subsection{Antioxidant activity}

\subsubsection{Reactive Oxygen Species scavenging capacity}

Reactive Oxygen Species (ROS) scavenging capacity of the extracts was evaluated by measuring scavenging activity on $\mathrm{DPPH}^{\bullet}$, FRAP and TRAP assays.

\subsubsection{DPPH assay}

The DPPH assay was performed as described previously by BrandWilliams ${ }^{24}$ with modifications Lakić ${ }^{3} .0 .1 \mathrm{~mL}$ the samples (from 0 to $4 \mathrm{mg} / \mathrm{mL}$ of the extracts) were mixed with $2.9 \mathrm{~mL} 50 \mu \mathrm{M} \mathrm{DPPH}{ }^{\bullet}$ solution was freshly prepared in ethanol. $2.9 \mathrm{~mL} 50 \mu \mathrm{M} \mathrm{DPPH}^{\bullet}$ solution with $0.1 \mathrm{~mL}$ ethanol was used as a control. The absorbance of the resulting solutions, control and the blank (with the reagents only) were recorded after $15 \mathrm{~min}$ at room temperature. Each sample was replicated three times. The disappearance of $\mathrm{DPPH}^{\bullet}$ was detected spectrophotometrically at $517 \mathrm{~nm}$. Percent radical scavenging capacity (RSC) was calculated by the following equation:

$$
\operatorname{RSC}(\%)=100 \% \times\left(\mathrm{A}_{\text {control }}-\mathrm{A}_{\text {sample }}\right) / \mathrm{A}_{\text {control }}
$$

From the obtained RSC (\%) values the $\mathrm{IC}_{50}$ value, which represent the concentrations of extracts that caused $50 \%$ neutralization, was determined by linear regression analysis.

\subsubsection{Ferric Reducing Antioxidant Potential (FRAP) Assay}

The ferric reducing power of plant extracts was measured as described Dudonné ${ }^{25}$ with modifications. This method is based on the reduction, at low $\mathrm{pH}$, of a colorless ferric complex $\left(\mathrm{Fe}^{3+}\right.$-tripyridyltriazine) to a bluecolored ferrous complex ( $\mathrm{Fe}^{2+}$-tripyridyltriazine) by the action of electrondonating antioxidants. The reduction is monitored by measuring the change of absorbance at $593 \mathrm{~nm}$. The working FRAP reagent was prepared daily by mixing 10 volumes of $300 \mathrm{mM}$ acetate buffer, $\mathrm{pH} 3.6$, with 1 volume of $10 \mathrm{mM}$ TPTZ (2,4,6-tri(2-pyridyl)-s-triazine) in $40 \mathrm{mM}$ hydrochloric acid and with 1 volume of $20 \mathrm{mM}$ ferric chloride. A standard curve was prepared using various concentrations of Trolox ${ }^{\mathrm{TM}}$. All solutions were used on the day of preparation. One hundred microliters of sample solutions and $300 \mu \mathrm{L}$ of deionized water were added to $3 \mathrm{~mL}$ of freshly prepared FRAP reagent. The reaction mixture was incubated for $30 \mathrm{~min}$ at $37^{\circ} \mathrm{C}$ in a water bath. Then, the absorbance of the samples was measured at $593 \mathrm{~nm}$. A sample blank reading using ethanol was also taken. The difference between sample absorbance and blank absorbance was calculated and used to calculate the FRAP value. In this assay, the reducing capacity of the plant extracts tested was calculated with reference to the reaction signal given by a Trolox ${ }^{\mathrm{TM}}$ solution. FRAP values were expressed as $\mathrm{mM}$ Trolox ${ }^{\mathrm{TM}}$. All measurements were done in triplicate.

\subsubsection{Total Reactive Antioxidant Potential (TRAP) assay}

The method developed by Romay ${ }^{26}$ was slightly modified in this experiment. A $10 \mathrm{mM}$ solution of ABAP (2,2'-azo-bis(2-amidino propane) was mixed with $150 \mu \mathrm{M}$ solution of ABTS (2,2'-azinobi(3-ethylbenzothiazoline6-sulfonic acid) in $100 \mathrm{mM}$ solution of PBS (phosphate buffered saline) a $\mathrm{pH}$ 7.4. The mixture was incubated at $45^{\circ} \mathrm{C}$ for $30 \mathrm{~min} .10 \mu \mathrm{L}$ of sample solution was added to $990 \mu \mathrm{L}$ of the resulting blue-green ABTS radical solution. The decrease of absorbance of TRAP solutions and ABTS as blank were recorded after $30 \mathrm{~s}$ at room temperature. Then, the absorbance of the samples was measured at $734 \mathrm{~nm}$. The total antioxidant capacity (TRAP) of extracts was expressed in $\mathrm{mM}$ Trolox ${ }^{\mathrm{TM}}$ equivalents (TEAC), using a standard curve of Trolox $^{\mathrm{TM}}(0-120 \mathrm{mg} / \mathrm{L})$. All measurements were replicated three times.

\subsection{Statistical analysis}

The data was reported as mean values \pm standard deviation (SD). In the case that the distribution is parametric data, there will be a One-Way ANOVA test. If the distribution is non-parametric, then tests like Kruskal-Wallis ANOVA will be used with a confidence level of $95 \%$. Values representing the concentrations of investigated extracts that cause $50 \%$ neutralization or inhibition $\left(\mathrm{IC}_{50}\right)$ were determined by linear regression analysis of $\mathrm{RSC}(\%)$, FRAP and TRAP results (STATISTICA 7.0 program).

\section{RESULTS AND DISCUSSION}

\subsection{Chemical composition}

Air dried and ground plant material $(0.5 \mathrm{~kg}$ for each of different organs) was extracted successively at room temperature with n-hexane (Hex), dichloromethane $\left(\mathrm{CH}_{2} \mathrm{Cl}_{2}\right)$, ethyl acetate $(\mathrm{EtOAc})$ and ethanol (EtOH). After removing of the solvents in vacuo, the dry extract was obtained for each organ from plant material (Table 1). All extracts were submitted to Antioxidant activity assays.

The major values of total phenolics are present in the extract of EtOAc of root $(0.47 \mathrm{mg} \mathrm{GAE} / \mathrm{g}$ dry extract), while the extract of stem (EtOAc) has a greater presence of anthraquinones $(4.86 \mathrm{mg} \mathrm{EE} / \mathrm{g}$ dry extract). The flavonoids and hydrolyzed sugar are concentrated in the extracts EtOAc $(99.12 \mathrm{mg} \mathrm{QE} / \mathrm{g}$ dry extract) and EtOH (21.87 mg GES/g dry extract) (see table 1).

One would expect to find larger amounts of phenolic substances (anthraquinones and flavonoids) in all organs collected but these were found mainly in the roots of the Muehlenbeckia hastulata, due to the properties attributed to this plant. These results could be related to phenolic compounds, particularly anthraquinones, which have laxative or purgative function, the most active $O$-glycosides ${ }^{21}$.

In the case of the sugars we have found a big amounts present into the extracts of root (EtOAc), this could be explained because sugars generally move from leaves to roots and they are usually absorbed in the form of starch or are simply metabolized by the plant. Although they do not exert biological activity in organisms by themselves, but they are used as protective agents of the active ingredients in order to maintain the integrity of thes $\mathrm{e}^{21,27}$.

The distribution of phytoconstituents in solvents shows that significant differences $(p<0.05)$, phenols (or reducing substances) are mainly found in the EtOAc and EtOH extracts, as well as flavonoids. While the anthraquinones are distributed essentially in EtOAc extracts and hydrolyzed sugars in extracts of EtOH. This phenomenon can be explained since the phenolic compounds derived have a high polarity, distributed in extracts of higher polarity. In the particular case of hydrolyzed sugars, it is common that they are in the EtOH extracts, especially compounds forming part of $O$-glycosylated or $C$-glycosylated.

Performing the analysis in plant organs, we found that there are significant differences $(p<0.05)$, we saw that phenols are mainly located in the root of the plant, while anthraquinones are on the stem. Also, flavonoids are concentrated in the leaves. However, the hydrolyzed sugars are evenly distributed in the plant organ.

On the other hand, the determination of phenols or reducing substances, performing relationship between the amount of these compounds and the polarity of the solvent extraction shows there are significant differences ( $p=$ 0.001) distributed mainly in the extracts of EtOAc and EtOH. However, in making this relationship in terms of plant parts, significant differences were also found $(p=0.000)$, indicating that the roots of quilo have most of such compounds. This may be because the roots of this plant are in contact with the ground, which is a potential redox system. This could explain that the plant can generate defense mechanisms, for example, the property of resisting a long time of extreme dryness and humidity ${ }^{12,13,15}$ 
Table 1. Amounts of dried extracts, total phenolics, anthraquinones, flavonoids and hydrolyzed sugar $( \pm \mathrm{SD})$ of Muehlenbeckia hastulata extracts.

\begin{tabular}{|c|c|c|c|c|c|c|}
\hline $\begin{array}{l}\text { Part } \\
\text { Plant }\end{array}$ & Extract & $\begin{array}{c}\text { Dried } \\
\text { extract (g) }\end{array}$ & $\begin{array}{l}\text { Phenolics } \\
\text { (GAE) }\end{array}$ & $\begin{array}{c}\text { Flavonoids } \\
\text { (QE) }\end{array}$ & $\begin{array}{l}\text { Sugars } \\
\text { (GES) }\end{array}$ & $\begin{array}{c}\text { Anthraquinones } \\
\text { (EE) }\end{array}$ \\
\hline \multirow{4}{*}{ Leaf } & Hexane & 7.65 & $0.008 \pm 0.003$ & $10.84 \pm 0.07$ & $0.04 \pm 0.00$ & $0.54 \pm 0.04$ \\
\hline & $\mathrm{CH}_{2} \mathrm{Cl}_{2}$ & 25.47 & $0.009 \pm 0.000$ & $51.92 \pm 1.38$ & $0.36 \pm 0.00$ & $0.85 \pm 0.23$ \\
\hline & EtOAc & 10.59 & $0.013 \pm 0.003$ & $99.12 \pm 2.04$ & $8.99 \pm 0.72$ & $2.50 \pm 0.04$ \\
\hline & $\mathrm{EtOH}$ & 72.46 & $0.014 \pm 0.000$ & $94.29 \pm 1.15$ & $21.87 \pm 0.12$ & $1.86 \pm 0.06$ \\
\hline \multirow{4}{*}{ Stem } & Hexane & 4.24 & $0.009 \pm 0.000$ & $6.48 \pm 0.26$ & $0.00 \pm 0.02$ & $1.22 \pm 0.10$ \\
\hline & $\mathrm{CH}_{2} \mathrm{Cl}_{2}$ & 3.27 & $0.013 \pm 0.000$ & $39.21 \pm 0.72$ & $1.69 \pm 0.05$ & $1.58 \pm 0.01$ \\
\hline & EtOAc & 3.84 & $0.020 \pm 0.000$ & $40.63 \pm 0.41$ & $13.03 \pm 1.29$ & $1.43 \pm 0.04$ \\
\hline & $\mathrm{EtOH}$ & 35.14 & $0.020 \pm 0.000$ & $21.77 \pm 0.46$ & $14.85 \pm 0.46$ & $2.49 \pm 0.10$ \\
\hline \multirow{4}{*}{ Root } & Hexane & 1.55 & $0.016 \pm 0.000$ & $0.00 \pm 0.00$ & $0.63 \pm 0.03$ & $4.86 \pm 0.12$ \\
\hline & $\mathrm{CH}_{2} \mathrm{Cl}_{2}$ & 1.43 & $0.017 \pm 0.000$ & $1.91 \pm 0.33$ & $0.71 \pm 0.03$ & $1.38 \pm 0.05$ \\
\hline & EtOAc & 2.38 & $0.023 \pm 0.000$ & $12.07 \pm 0.59$ & $7.47 \pm 0.02$ & $0.84 \pm 0.00$ \\
\hline & $\mathrm{EtOH}$ & 14.88 & $0.022 \pm 0.000$ & $25.57 \pm 0.10$ & $14.32 \pm 0.88$ & $0.93 \pm 0.02$ \\
\hline
\end{tabular}

For the flavonoids, the relationship between the amount of these compounds and the polarity of the solvent extraction indicates that there are significant differences $(p=0.001)$, distributing into the highest polarity extracts (EtOAc and EtOH). On the other hand, considering only the parts of the plant, these showed significant differences $(p=0.001)$, leading to the leaf of the plant with higher values in comparison to other organs. The previous result has a close relation to the effect of UV-B photoprotection, preventing from the decomposition of chlorophyll.

The hydrolyzed sugar, has a relationship between the amount of these compounds and the polarity of the solvent extraction showing that there are significant differences $(p=0.000)$, where EtOH extracts are those with the highest concentration of such metabolites. However, in performing the same comparison among quilo parts we can see that there are no significant differences $(p=0.941)$, distributing these structures equally in the plant. The correlations between antioxidant activities and the amount of metabolites present in each of the organs how that there is, in general, a dependence of phenolic compounds and flavonoids on the activities measured.

For the case of the determination of anthraquinones, in making the relationship between the amounts of such compounds and the polarity of the extracting solvents, it is appreciated that there are significant differences ( $p$ $=0.003$ ), mainly distributed in EtOAc extracts. However, when making the relationship between the amounts of anthraquinone and different parts, it is shown that there are significant differences $(p=0.039)$, indicating metabolites are concentrated in the stem.

3.2 Antioxidant activity

The antioxidant activity of Muehlenbeckia hastulata extracts was evaluated in a series of in vitro tests. Each of these assays is based on one feature of antioxidant activity, which is the ability to scavenge or the ability to evaluate the reducing power. Multiple in vitro methods for the evaluation of the antioxidant activities of different plant products are recommended because the composition of plant extracts is complex ${ }^{28,29}$. Thus, the antioxidant properties of the examined Muehlenbeckia hastulata extracts were evaluated as free radical scavenging capacity (RSC) as well as TRAP and FRAP. In the DPPH-test, the ability of examined extracts to act as donors for hydrogen atoms or electrons to reduce DPPH ${ }^{\bullet}$ into DPPH-H was measured spectrophotometrically. Assessed extracts, made from Muehlenbeckia hastulata, were able to reduce the stable radical $\mathrm{DPPH}^{\bullet}$ to the yellow coloured DPPH-H, the experiments confirmed that free radical scavenging activity of all leaves extracts reaching a $50 \%$ reduction with an $\mathrm{IC}_{50}$ of $0.60 \mathrm{mg} / \mathrm{mL}$ to $43.42 \mathrm{mg} / \mathrm{mL}$. (See table 2). The extracts were active against the DPPH solution, however extracts of EtOAc, EtOH and $\mathrm{CH}_{2} \mathrm{Cl}_{2}$ (only the stem extract) have an activity comparing with Trolox $\left(\mathrm{IC}_{50} 10.52 \mathrm{mg} / \mathrm{mL}\right.$ ). This may be because the extracts have a complex mixture of compounds with potential antioxidant activity (phenols, flavonoids, anthraquinones, etc.), which may have synergistic effect, increasing the activity of the extract. Moreover, it has been reported that the plant Muehlenbeckia platyclada (plant from Peru) possesses an antioxidant activity mainly in the extract of EtOAc and this extract, the most active of all, however, does not have any information about the content of phytochemicals ${ }^{30}$.

The Total Antioxidant Capacity (TAC) of extracts from different parts of the quilo (leaf, stem and root) using two different assays was evaluated. TAC values of the extracts for each assay are shown in Table 2. In examining results of the FRAP assays, EtOAc and EtOH extract of leaves, stem and roots had the greatest antioxidant capacity, in the same manner as in the TRAP assay. The high antioxidant capacity of the EtOAc and EtOH extract of leaves is due to the large amount of free phenols present.

Table 2. $\mathrm{IC}_{50} \mathrm{DPPH}^{\bullet}$ and TEAC $\mathrm{mM}$ of FRAP and TRAP $( \pm \mathrm{SD})$ values of extracts of Muehlenbeckia hastulata.

\begin{tabular}{|c|c|c|c|c|}
\hline $\begin{array}{l}\text { Part } \\
\text { Plant }\end{array}$ & Extract & $\begin{array}{c}\mathrm{IC}_{50} \mathrm{DPPH}^{\bullet} \\
(\mathrm{mg} / \mathrm{mL})\end{array}$ & $\begin{array}{c}\text { FRAP } \\
\left(\begin{array}{c}\text { mM Trolox } \\
\text { TM) }\end{array}\right.\end{array}$ & $\begin{array}{c}\text { TRAP } \\
\left(m \text { Trolox }^{\mathrm{TM}}\right)\end{array}$ \\
\hline \multirow{4}{*}{ Leaf } & Hexane & $20.70 \pm 0.08$ & $0.13 \pm 0.01$ & $60.38 \pm 3.34$ \\
\hline & $\mathrm{CH}_{2} \mathrm{Cl}_{2}$ & $11.23 \pm 0.15$ & $0.16 \pm 0.02$ & $102.77 \pm 2.74$ \\
\hline & EtOAc & $5.79 \pm 0.00$ & $0.17 \pm 0.02$ & $206.91 \pm 3.70$ \\
\hline & $\mathrm{MeOH}$ & $2.19 \pm 0.01$ & $0.51 \pm 0.01$ & $299.06 \pm 27.41$ \\
\hline \multirow{4}{*}{ Stem } & Hexane & $27.33 \pm 0.80$ & $0.05 \pm 0.00$ & $61.59 \pm 5.00$ \\
\hline & $\mathrm{CH}_{2} \mathrm{Cl}_{2}$ & $5.80 \pm 0.06$ & $0.12 \pm 0.00$ & $75.76 \pm 1.06$ \\
\hline & EtOAc & $1.33 \pm 0.05$ & $1.42 \pm 0.00$ & $245.26 \pm 16.49$ \\
\hline & $\mathrm{MeOH}$ & $0.60 \pm 0.48$ & $1.44 \pm 0.01$ & $240.36 \pm 7.51$ \\
\hline \multirow{4}{*}{ Root } & Hexane & $43.42 \pm 0.78$ & $0.05 \pm 0.00$ & $80.66 \pm 4.60$ \\
\hline & $\mathrm{CH}_{2} \mathrm{Cl}_{2}$ & $11.11 \pm 0.93$ & $0.59 \pm 0.02$ & $148.79 \pm 7.54$ \\
\hline & EtOAc & $0.74 \pm 0.02$ & $1.54 \pm 0.03$ & $309.04 \pm 15.45$ \\
\hline & $\mathrm{MeOH}$ & $0.75 \pm 0.02$ & $1.75 \pm 0.02$ & $308.49 \pm 10.28$ \\
\hline
\end{tabular}

Observing all these values and relating then to the polarity of the solvents, we noticed significant differences $(p<0.05)$, distributed mainly in EtOAc and $\mathrm{EtOH}$ extracts. However, in making a comparison of this activity with the plant organ it is appreciated that there are no significant differences $(p>0.05)$, indicating an equal distribution of this activity in the plant.

For the DPPH activity, in all the organs there is a correlation between flavonoids and $\mathrm{DPPH}^{*} \mathrm{RSC}$ (between $\mathrm{R}^{2}=0.667$ and 0.939 ), so this activity 
depends on the concentration of these metabolites.

The FRAP activity, in the leaves, stem, possesses a dependency on the activity in the presence of phenolic compounds and hydrolyzed sugars $\left(\mathrm{R}^{2}=\right.$ between 0.410 and 0.981 , see table 3). Moreover, in the root of quilo, there is a dependency on the amount of flavonoids $\left(\mathrm{R}^{2}=0.906\right)$. This may be due to a flow through the plant metabolites, subject to transformation into other phenolic compounds.

Finally, TRAP activity, in the leaves, stem and root, possesses a dependency on the activity in the presence of phenolic compounds $\left(\mathrm{R}^{2}=0.661,0.993\right.$ and 0.965 , respectively). Also, it can be seen a dependency on the amounts of sugar hydrolysed with this activity (between 0.766 and 0.984 , see table 3 ) because the possibility of the osidic portion is donate $\mathrm{H}^{\bullet}$ for reducing the concentration of TRAP solutions.

Table 3: $\mathrm{R}^{2}$ values for the correlation of data between trials and amount of antioxidant metabolites.

\begin{tabular}{|c|c|c|c|c|}
\hline Part Plant & Metabolite & DPPH & FRAP & TRAP \\
\hline \multirow{4}{*}{ Leaf } & Phenol & 0.598 & 0.410 & 0.661 \\
\cline { 2 - 5 } & Flavonoid & 0.939 & 0.330 & 0.785 \\
\cline { 2 - 5 } & Sugar & 0.698 & 0.887 & 0.935 \\
\cline { 2 - 5 } & Anthraquinones & 0.668 & 0.158 & 0.616 \\
\hline \multirow{4}{*}{ Stem } & Phenol & 0.795 & 0.928 & 0.933 \\
\cline { 2 - 5 } & Flavonoid & 0.607 & 0.104 & 0.126 \\
\cline { 2 - 5 } & Sugar & 0.599 & 0.981 & 0.984 \\
\cline { 2 - 5 } & Anthraquinones & 0.210 & 0.171 & 0.198 \\
\hline \multirow{4}{*}{ Root } & Phenol & 0.677 & 0.924 & 0.965 \\
\cline { 2 - 5 } & Flavonoid & 0.676 & 0.906 & 0.831 \\
\cline { 2 - 5 } & Sugar & 0.471 & 0.824 & 0.766 \\
\cline { 2 - 5 } & Anthraquinones & 0.393 & 0.146 & 0.085 \\
\hline
\end{tabular}

\section{CONCLUSIONS}

The measurement of antioxidant activity by DPPH RSC, FRAP and TRAP assay was used as a method for the evaluation of quilo extracts which have not been reported previously. The comparison of antioxidant activities $\left(\mathrm{IC}_{5}\right.$ values) of investigated extracts (table 2 ) showed variable effects that depended on examined extracts and the model systems used for evaluation. Based, on the distribution of metabolites quantified in each of the organs, it can be seen that antioxidant activity (measured with DPPH, FRAP and TRAP assays) is scattered in all organs. However, we must emphasize that this activity is mainly focused on EtOAc and EtOH extracts, which have significant amounts of phenolic compounds, anthraquinones and flavonoids. In the future you can make a bioguided study for the discovery of new compounds with antioxidant activity in these plant extracts.

\section{ACKNOWLEDGEMENTS}

The authors thank the Dirección de Investigación y Postgrado (DGIP) of the Universidad Técnica Federico Santa María for financing this work through the grant $\mathrm{N}^{\circ}$ 13.11.36 (2011-2012), PIIC QUI 2011 and PAC 2012 for A.M.

\section{REFERENCES}

1. R.A. Garza-Padrón, M.J. Verde-Star, M.E. Morales-Rubio, A. OrandayCárdenas, C. Rivas-Morales, M.A. Núñez-González y M.P. BarrónGonzález. Polibotánica. 30,111, (2010).

2. Choudhary, A., Sharma, R., Nagar, M., Mohsin M. and Sahay Meena, H J. Chil. Chem. Soc. 56, 911-917 (2011).

3. Lakić, N., Mimica-Dukić, N., Isak, J., Božin, B. Centr. Eur. J. Biol. 5, 331 (2010)

4. Pellegrini, N. Serafini, M., Colombi, B., Del Rio, D., Salvatore, S., Bianchi, M., Brighenti, F. J. Nutr. 133, 2812, (2003).

5. Carlsen, H., Myhrstad, M., Thoresen, M., Uivind Moskaug, J., Blomhoff, R. The journal of nutrition. 133, 2137 (2003).

6. Heo, H. J., and Lee, C.Y. J. Agric. Food Chem. 53(6), 1984 (2005)
7. Subashini R.; Roopan S. Mohana; Khan F. Nawaz. J. Chil. Chem. Soc. 55, 317-319 (2010).

8. Fukumoto, L. R. and Mazza, G. J. Agric. Food Chem. 48, 3597, (2000).

9. Gow-Chin, Y., Pin-Der, D., Da-Yon, C. Food Chemistry. 70, 437 (2000).

10. Rangkadilok, N., Worasuttayangkurn, L., Bennett, R. N. and Satayavivad, L. J. Agric. Food Chem. 53(5), 1387 (2005).

11. Nickavar, B., Alinaghi, A., Kamalinejad, M. Iranian Journal of Pharmaceutical Research. 7:203 (2008).

12. Erazo, S., Muñoz, O., García, R., Lemus, I., Backhouse, N., Negrete, R., San Feliciano, A., Delporte, C. Z. Naturforsch.57c:801(2002).

13. Montes, M., Wilkomirsky, T. Medicina Tradicional Chilena. Editorial Universidad de Concepción: Chile. 1985; pp.138.

14. Red de Protección Social. Medicamentos herbolarios Chilenos, 103 especies vegetales. Ministerio de Salud - Gobierno de Chile. 2009; pp. 161-162.

15. Hoffman, A. Flora Silvestre de Chile Zona Central $2^{\text {da }}$ edición. Fundación Claudio Gay. Chile. 1978; pp.94.

16. Riedemann, P., Aldunate, G. Flora Nativa de Valor Ornamental Zona Centro de Chile. Editorial Andrés Bello: Chile. 2001; p.186-187.

17. Yasuda, T., Yamaki, M., Iimura, A., Shimotai, Y., Shimizu, K., Noshita, T., Shinji, F. J Nat Med. 64:206, (2010).

18. Waterman, P., Mole, S. Analysis of Phenolic plant metabolites, Blacwell Scientific University. Malasi, 1994; pp.116-133.

19. Köhler, H., Contreras, R., Zúñiga, G. Biological Research. 40, suppl. A, R 124. (2007).

20. Meda, A., Lamien, C., Romito, M., Millogo, J., Nacoulma, O. Food Chemistry. 91, 571, (2005)

21. Bruneton, J. Farmacognogsia. Fitoquímica y plantas medicinales, $2^{\text {da }}$ edición, Editorial Acribia, España, 2001; pp.142 and 153.

22. Domínguez, X. Métodos de investigación fitoquímica, Editorial Limusa S.A., España, 1973; pp. 419

23. Mellado, M., M. Sc, "Estudio Fitoquímico de los Metabolitos Principales y Extractos de Muehlenbeckia hastulata Johnst con Potencial Actividad Antioxidante y Antifúngica (Candida albicans, Candida parapsilosis y Exophiala dermatitidis)", Universidad Técnica Federico Santa María, Chile, 2012.

24. Brand-Williams, W. Cuvelier, M., Berset, C. Lebensm Wiss u Technol., 28, 25, (1995).

25. Dudonné, S., Vitrac, X., Coutière, P., Woillez, M. and Mérillon, J.M. J. Agric. Food Chem. 57, 1768, (2009).

26. Romay, C., Pascual, C., Lissi E.A. Brazilian J. Medical and Biological Research. 29, 175, (1996).

27. Berezov, T.T., Korovkin, B.F., Chemistry and metabolism of carbohydrates. En Berezov TT, Korovkin BF (eds): Biochemistry, $1^{\text {a }}$ Ed. Editorial Mir Publishers Moscow Russia, 1992; pp. 215-256.

28. Chu Y.H., Chang C.L., Hsu H.F. J. Sci. Food Agric. 80, 561, (2000)

29. Nuutila A.M., Puupponen-Pimia R., Aarni M., Oksman-Caldentey K.M. Food Chem. 81, 485, (2003).

30. Siriwatanametanon, N., Fiebich, B. L., Efferth, T., Prieto, J. M., Heinrich, M. Journal of Ethnopharmacology, 130,196-207, (2010). 